\title{
Democratization
}

\section{Authoritarian innovations in Indonesia: electoral narrowing, identity politics and executive illiberalism}

\section{Marcus Mietzner}

To cite this article: Marcus Mietzner (2019): Authoritarian innovations in Indonesia: electoral narrowing, identity politics and executive illiberalism, Democratization, DOI: $10.1080 / 13510347.2019 .1704266$

To link to this article: https://doi.org/10.1080/13510347.2019.1704266

曲 Published online: 23 Dec 2019.

Submit your article to this journal $₫$

Q View related articles $\sqsubset$

View Crossmark data $\asymp$ 


\title{
Authoritarian innovations in Indonesia: electoral narrowing, identity politics and executive illiberalism
}

\author{
Marcus Mietzner \\ Coral Bell School of Asia Pacific Affairs, Australian National University, Canberra, Australia
}

\begin{abstract}
In the last decade, autocrats and democrats alike have used a wide range of innovative illiberal methods to cement or expand their power. Especially in democracies, however, these techniques have often been difficult to detect as they are typically packaged as acts of democracy defense, not erosion. This article discusses the deployment of authoritarian innovations in Indonesia, where the elite as a collective, the opposition and the executive each launched illiberal initiatives that caused a notable decline in the country's democratic quality. These illiberal strategies concern a narrowing of electoral competitiveness, the mobilization of identity politics, and attempts at power concentration and maximization by the executive. The wide spread of antidemocratic actors in Indonesia differs from other cases of increasing illiberalism, in which executive leaders have been the main drivers. But Indonesia also stands out because the residual resources of its defective but persistent electoral democracy have mitigated the effectiveness of the authoritarian innovations, preventing (thus far) the polity's full descent into autocracy or populist illiberalism.
\end{abstract}

ARTICLE HISTORY Received 30 June 2019; Accepted 7 December 2019

KEYWORDS Indonesia; illiberalism; democracy; authoritarianism; elections

Since the late 2000s, democracy scholars have debated whether a global democratic recession exists, and if so, how significant it is. ${ }^{1}$ For their part, authors who believe in the notion of democracy's worldwide backsliding have highlighted the broad spectrum of polities affected by this phenomenon. Larry Diamond, for instance, identified three types of regimes experiencing democratic decline since about 2006. First, he pointed out that "the quality or stability of democracy has been declining in a number of large and strategically important emerging-market countries". ${ }^{2}$ Second, "authoritarianism has been deepening, including in big and strategically important countries". In other words, already authoritarian countries become even more autocratic. And third, "the established democracies, beginning with the United States, increasingly seem to be performing poorly". This means that trends of democratic decline have taken place across a wide range of regime types, and within those, on the full spectrum of democratic quality: from established democracies that see their democratic traditions slowly but consistently eroding to long-term autocracies that try to further consolidate their grip on power. 
Thus, while the recent onset and the extent of democratic recession suggests that new authoritarian methods are being used to undermine democratic norms and institutions, Diamond's findings remind us that authoritarian innovations are not a monopoly of autocrats. Indeed, they are just as likely to be applied in democratic regimes, and they might not be easily identifiable as full democratic reversals. In many cases, authoritarian innovations in democratic environments produce gradual erosions of democracy's quality that benefit incumbents and elites more broadly, while the democratic framework is nominally maintained. ${ }^{3}$ Consequently, analysing authoritarian innovations in democratic contexts involves more below-the-surface examinations than studying them in non-democratic regimes, as such innovations are - in the conceptualization of Diego Fossati and Nicole Corato - "insidious practices designed to shrink spaces for democratic participation", aiming to "camouflage their anti-democratic qualities and intentions by invoking the language of 'rule of law' or 'will of the people' while simultaneously subverting the mechanisms that ensure the integrity of these democratic safeguards". 4

Indonesia is one example of a major new democracy in which authoritarian innovations have been deployed behind the façade of a widely celebrated electoral democracy. The world's third largest democracy since the downfall of long-time autocrat Suharto in 1998, Indonesia entered a phase of democratic consolidation quicker and more successfully than many of its regional (or even global) counterparts. ${ }^{5}$ But subsequently it began to stagnate and erode so slowly that many observers struggled to make sense of the direction of its democratic development. ${ }^{6}$ While still an electoral democracy today, its democratic quality has declined, in some areas significantly so. ${ }^{7}$ This decline was driven by the "insidious" practices hinted at above, often packaged as initiatives designed to sustain, not to undermine, democratic rights. As a result, Indonesian democracy has fallen behind previous achievements in its democratic consolidation process; put differently, it has de-consolidated while clinging on to its democratic status. ${ }^{8}$

This article discusses Indonesia's authoritarian innovations in three key arenas of democratic quality. The first concerns a gradual narrowing of electoral competitiveness, due to increasingly restrictive entry regulations that have driven up political costs. Second, some segments of the political elite have weaponized identity politics, with minorities being the main victims of this trend. Third, while oppositional forces were mainly responsible for the surge of identity politics, the executive responded by using exceedingly illiberal instruments to defend its position. This involved the use of the security forces against critics; utilization of government agencies for electoral purposes; and government exploitation of increasing ownership concentration in the media. In combination, these trends undermined what Wolfgang Merkel identified as pillars of "embedded" democracies (i.e. stable constitutional democracies that are situated in a number of enabling conditions). Merkel's conditions are used in this article to assess the damage Indonesia's authoritarian innovations have done to the country's democratic fabric. Three of Merkel's key conditions for democratic stability haven been particularly affected: a level playing field for contestants in elections; protections of civil rights; as well as strong controls and constraints on the executive. ${ }^{9}$

In comparative terms, this article shows that not only are authoritarian innovations applied in different regime types with various levels of democratic quality - they are also deployed by a wide range of actors. While much of the literature on new and old authoritarian techniques is focused on executive leaders such as Trump, Erdogan or Orban, ${ }^{10}$ 
the Indonesian case points to three distinct actors using authoritarian instruments: first, the elite as a collective (in the field of electoral narrowing); second, an anti-democratic opposition (which exploited identity politics); and third, an executive determined to neutralize opposition attacks through illiberal means. Their actions, while mirroring those applied in other countries and contexts, developed their innovative force in causing a momentous disruption in Indonesia's democratization process. This process, which included a successful democratic transition between 1998 and 2004 as well as an early period of democratic consolidation between 2004 and the late 2000s, is now in doubt.

\section{Electoral narrowing}

For Wolfgang Merkel, ${ }^{11}$ "open, pluralistic competition for central power positions is the distinguishing difference between democracy and autocracy". Such competitiveness requires that citizens do not face undue restrictions to forming parties and participating in elections. However, as democracies also require stability to function effectively, the right of citizens to participate in elections (and to have a wide range of choices as voters) needs to be counterbalanced against the necessity to prevent the atomization of the party system. In addition, ethnically, religiously and socially diverse countries tend to seek limitations on party formation in order to avoid the emergence of ethno-religious or regionalist parties that threaten the existence of heterogeneous nation states. ${ }^{12}$

The need to balance competitiveness with the prevention of fragmentation also informed the formulation of party and electoral laws in post-authoritarian Indonesia. In order to qualify for the 1999 elections, parties had to have branches in $50 \%$ of all provinces and in $50 \%$ of the districts in those provinces. This was done with the explicit goal of forcing parties to offer a cross-regional platform. ${ }^{13}$ In addition, a rather unusual electoral threshold was established: parties receiving less than $2 \%$ of the votes could take up their seats in parliament, but were barred from running in the next elections. This form of electoral engineering was widely praised as a democratic way to consolidate the party system and avoid ethno-religious sentiments from entering the system. ${ }^{14}$ But because the imposed restrictions initially had little effect on party system consolidation (there were 48 parties participating in the 1999 elections, 20 of which took seats in parliament), the elite continued to tighten them: the requirement to possess branches in the regions was raised to two thirds for the 2004 and 2009 elections, and to $100 \%$ for 2014 and 2019. At the same time, the electoral threshold was transformed into a parliamentary threshold for the 2009 elections, and raised from $2.5 \%$ to $3 \%$ for the 2014 elections and $4 \%$ for 2019 .

This gradual tightening of electoral participation rules occurred so slowly that it is difficult to pinpoint the exact juncture at which it evolved from an acceptable instrument of securing democratic effectiveness into an elite tool of excluding party newcomers. But retrospectively, the increase to $100 \%$ branch coverage for the 2014 elections could no longer be justified with reference to avoiding localist parties. Instead, it signalled a clear intent by the existing parliamentary parties to drive up the cost of new party formations. Similarly, the fixing of the parliamentary threshold at $4 \%$ for the 2019 polls reflected the elite's determination to pick a threshold that all incumbent parties could pass, but would make it very difficult for newcomers to enter the legislature. Obscuring these elite intentions was the fact that most of the ten parliamentary 
parties of the 2014-2019 term were likely to survive and continue to contest power among each other - a circumstance that conveniently protected the image of Indonesia's ongoing electoral competitiveness. Indeed, this competitiveness remained high and an important component of electoral democracy, but it had now transformed into a system of intra-incumbency contestation that excluded other forces trying to penetrate it.

A comparison of new party formations in the late 1990s and 2000s with the new actors emerging ahead of the 2019 elections highlights the impact of the tightened party regulations. Between 1999 and 2009, some labour-based parties existed, which stood in the tradition of anti-Suharto unions. ${ }^{15}$ These labour parties were limited in their outreach and failed to gain seats in the national legislature, but won representation in a few provincial parliaments. After 2009, however, they disappeared. Some Muslim micro-parties, still prominent in the first decade after the transition, also vanished in 2009. Ahead of the 2019 elections, a different type of newcomer party filled that vacancy: that is, parties with strong financial backing from wealthy actors. For 2019, these were: the Indonesian Unity Party (Partai Persatuan Indonesia, Perindo), founded by billionaire Hary Tanoesoedibjo; the Working Party (Partai Berkarya), established by Suharto's son Tommy; the Indonesian Transformation Movement Party (Partai Gerakan Perubahan Indonesia, Partai Garuda), widely believed to have links to the Suharto family too; and the Indonesian Solidarity Party (Partai Solidaritas Indonesia, PSI), a reformist party supported by a wealthy former legislator. ${ }^{16}$ Their significant resources notwithstanding, even these parties failed to meet the parliamentary threshold in 2019, with only incumbent parties returning to parliament in that year.

A similar trend was observable in relation to the presidential nomination threshold. When direct presidential elections were introduced in 2004, the nomination threshold for parties was temporarily set at 3\% of the seats (or 5\% of the votes) received in the preceding parliamentary elections. That went up to $20 \%$ of the seats (or $25 \%$ of the votes) for the 2009 and 2014 elections. Before the 2019 elections, the Constitutional Court decided that parliamentary and presidential elections had to be held concurrently. Logically, this would have meant the need to phase out the parliamentary election result as a benchmark for presidential nominations. But the majority of the parties agreed to instead use the 2014 legislative results for the 2019 nominations, and to maintain the existing thresholds. ${ }^{17}$ While defended as a measure to encourage coalition building and give presidents working majorities in parliament, the tightening thresholds reduced the field of nominees and, therefore, the choice for voters: the number of presidential candidates decreased from five in 2004 to three in 2009 and two in 2014. In 2019 , the same two presidential nominees re-registered, underlining the narrowing electoral range.

A comparable pattern took hold in the election of local government heads (i.e. for governors, mayors and district heads). When introduced in 2005, nominees had to gain the support of parties that held at least $15 \%$ of the seats in the relevant local legislature. This went up to $20 \%$ of the seats (or $25 \%$ of the votes) in 2014 . When the Constitutional Court decided in 2007 to allow independent candidates to run without party support, lawmakers stipulated that nominees had to collect a large number of signatures to qualify (in West Java, for instance, a candidate would have to obtain more than two million signatures). Both the increased party support requirements and the signature thresholds for independent candidates added to the financial burden of nominees: parties expect payments for declaring their support, as do signature collectors hired 
by independents. These developments combined with a general increase in campaign costs (discussed below) to trigger a spike in the number of uncontested elections after 2015. Prior to that, there had been no single-candidate elections. In 2015, three elections were uncontested (1.1\% of all races); in 2017 , there were nine (8.9\%); and in $2018,16(9.4 \%){ }^{18}$

As indicated above, this tightening of electoral participation rules occurred in the context of escalating campaign costs. In addition to increased costs caused by raised registration or nomination thresholds, parties and nominees also had to pay a growing amount of money for consultants; campaign team members; vote buying; social media activity; conventional advertising; and a host of other election-related expenses. ${ }^{19}$ To be sure, this trend is global in nature. But many democracies responded by increasing state subsidies for parties as well. ${ }^{20}$ Indonesia, by contrast, reduced its public party funding in 2005 by about $90 \%$ (from then $\$ 0.10$ per vote to roughly $\$ 0.01){ }^{21}$ Although Indonesia returned in 2017 to the old funding regime of $\$ 0.10$ per vote, political costs had exploded in the 12 years interim to such an extent that the increase did little to address the real expenditure pressures. Consequently, Indonesia's political finance system remains almost entirely reliant on the self-funding capabilities of parties and nominees, and the willingness of the state to turn a blind eye to the illegality of their fundraising.

In this situation, even initiatives designed to increase electoral competitiveness turned, paradoxically, into the opposite. In 2008, the Constitutional Court (importantly, not party elites) decided to enact a fully open party list system for legislative elections. In that system, the party candidate with the most individual votes receives the seat won by the party, regardless of his or her position on the ranked nomination list. This shifted the focus of legislative elections from inter-party competition to intra-party contests between individual nominees. Most significantly, the changed institutional setting led to an unprecedented upsurge in vote buying, and thus further increased political costs. $^{22}$ In turn, it also altered the socio-economic background of legislators: the number of business people in parliament changed from $45 \%$ in 1999 to $52 \%$ in $2014 .^{23}$ Hence, the open party list system further narrowed the field of legislative hopefuls to those with sufficient financial resources. ${ }^{24}$

One of the most effective features of Indonesia's electoral narrowing has been the fact that it has rarely been recognized as an authoritarian innovation collectively devised by the elite. Elections in Indonesia have continued to take place regularly, and are contested by a significant number of parties and candidates - including in 2019. At the same time, many civil society groups welcomed the heightened barriers to political party formation as a useful means of party system consolidation. But meaningful party system consolidation can only take place in a regime that creates conditions for healthy political funding. In a system reliant on political self-funding (such as Indonesia's), electoral narrowing does not "rationalize" the party system - it hands power to an ever-smaller circle of affluent elites. Consequently, Indonesia's electoral regime remains competitive within its limited elite arena - but this arena continues to shrink, systematically excluding anti-status quo actors.

\section{Identity politics}

While there had been differences among party elites about details of the electoral narrowing project (some leaders, for instance, rejected maintaining the presidential 
nomination threshold for the 2019 elections), it had overall been a collective elite effort. In that sense, parties acted as a cartel, as Katz and Mair had observed in Western Europe $^{25}$ or Dan Slater for the Indonesian case. ${ }^{26}$ In other authoritarian innovation initiatives, however, the parties operated against each other rather than in defense of joint interests. This pattern became particularly pronounced in the instrumentalization of identity politics as an electoral tool by some political actors against others.

In conceptualizing identity politics, I follow Fukuyama's exclusionary, belligerent and politicized interpretation of the term. This stands in contrast to democratically healthier manifestations of identity politics, in which previously underprivileged groups use their identity to rally around a common cause. ${ }^{27}$ According to Fukuyama, identity politics emerges from a "moral idea [which] tells people that they have authentic inner selves that are not being recognized and suggests that external society may be false and repressive. It focuses people's natural demand for recognition of their dignity and provides language for expressing the resentments that arise when such recognition is not forthcoming" ${ }^{28}$ In most cases of identity politics, political actors harvest the resentments of a socio-demographic majority to mobilize against minorities seen as threatening the majority's identity. Campaigns based on identity politics, therefore, often coincide with the questioning, or open violation, of minority citizens' civil rights. As such, identity politics hollow out another of Merkel's foundations of embedded democracy. Constitutionally anchored civil rights, for Merkel, are at the heart of the rule of law principle; hence, "decisions concerning these rights have to be put out of reach of any majority of citizens or parliament, [or] otherwise, majoritarian democracies could turn into the "tyranny of the majority". ${ }^{29}$

To be sure, identity politics is not a new phenomenon in Indonesia. It underpinned many of the socio-political conflicts of the 1950s and 1960s, and Suharto's New Order also used it as part of its "divide and rule" strategy. Even at its very end, Suharto tried to blame Indonesia's ethnic Chinese minority for the country's economic collapse, with his son-in-law Prabowo Subianto (then a senior general) acting as the main field operator in this campaign in early $1998 .{ }^{30}$ But after the regime change, identity politics initially took the shape of religio-ideological diversification rather than polarization. Religiopolitical groups of all colours formed their own parties, hoping to secure privileges for their own followers. In the 1999, 2004 and 2009 national elections, polarizing ideological questions (mainly related to the divide between those advocating an institutionalized role for Islam in state organization and those promoting a pluralist interpretation of the constitution) took a back seat to the personality differences between the various presidential candidates. Indeed, Susilo Bambang Yudhoyono, who won the 2004 and 2009 elections, owed his success to no small extent to his ability to appeal to both sides of that Islamist-pluralist divide. ${ }^{31}$

It was only in 2014 that identity politics was used as an electoral instrument extensively, and openly, at the national stage. Not coincidentally, identity politics surged in concert with the presidential candidacy of Prabowo Subianto, who revived some of the elements of his 1998 anti-Chinese campaign. In barely veiled terms, Prabowo portrayed ethnic Chinese elites as assistants of a foreign conspiracy to rob Indonesia of its natural resources. ${ }^{32}$ As in the final days of Suharto's regime, Prabowo was supported by a wide range of Islamist groups. These groups denounced Prrabowo's only challenger, the pluralist Joko Widodo (or "Jokowi"), as a "bringer of disasters" for the Muslim community. ${ }^{33}$ During the campaign, Prabowo's Islamist allies spread rumours that Jokowi was, in fact, the son of a Singaporean Chinese (combining the racist and xenophobic 
elements of the campaign's message), and - on top of that - part of a family connected to the long-destroyed Indonesian Communist Party (Partai Komunis Indonesia, PKI). Jokowi, for his part, spent much of his campaign trying to convince voters that these insinuations were false.

The attack on a religio-ethnic minority, and the linking of an electoral opponent to that minority, signalled a new level of polarization in Indonesian democratic politics. This polarization was partly due to Prabowo's choice of a radical campaign technique - but it was also assisted by the narrowing electoral field described in the previous section. In 2004 and 2009, the larger number of presidential candidates had produced much more multi-layered dynamics than those inherent in a head-to-head scenario. In 2009, Prabowo had run as vice-presidential candidate to former president Megawati Sukarnoputri, a pluralist, and had faced two other pairs with varying levels of Islamic credentials - making a campaign based on identity politics neither possible nor promising. At the same time, the disappearance of the micro-parties after 2009 also simplified the ideological positioning of each remaining party, and with a few exceptions, they fell firmly onto their predicted side in the divide between Islamists and pluralists in the 2014 presidential contest.

While Jokowi eventually prevailed in the election, $47 \%$ of Indonesians had supported a campaign that mixed identity politics with other anti-democratic messages. These messages included a proposal to return to the pre-democratic constitution and musings about whether elections were, as a "Western import", appropriate for the Indonesian polity. ${ }^{34}$ Thus, identity politics was defeated in 2014, but only narrowly so - ensuring that it would continue to be seen as a viable electoral strategy. It was also significant that unlike his predecessor Yudhoyono, Jokowi opted to marginalize Islamist groups from the state infrastructure after the election - adding to the continued virulence of identity politics. ${ }^{35}$ This preserved and bottled-up potential of identity politics found an outlet in 2016, when Prabowo and his Islamist associates decided to turn against Basuki Tjahaja Purnama (or "Ahok"), the Chinese-Christian governor of Jakarta. Ahok, Jokowi's former deputy and a close ally of the president, was seeking re-election in a ballot scheduled for early 2017. Prabowo nominated an Islamic intellectual to challenge Ahok, while Yudhoyono also joined the contest by supporting his son's candidacy. When Ahok made a controversial remark about a Qur'anic verse in September 2016, both Prabowo and Yudhoyono used the chance to accuse their rival of blasphemy.

The Islamist mass mobilization that followed has been documented in detail elsewhere. $^{36}$ Suffice to recall here that Islamist groups organized in unprecedented numbers against Ahok, who subsequently lost the election against Prabowo's nominee and received a two-year prison sentence on the blasphemy charge. Identity politics, as an authoritarian intervention in democratic politics, had finally proven successful. Importantly, however, it was not deployed - in the Indonesian case - by an incumbent leader or government party to manipulate the electorate into rejecting challenges to their rule. Instead, identity politics was used by an oppositional figure as an electoral device to gain power, and - when that failed - to damage the incumbent president. Thus, while many contemporary authoritarian initiatives around the world are still launched by executives in order to consolidate power, it is crucial to recognize that they are almost as likely to come from political actors without executive or legislative authority. Incumbency, in other words, is no longer the place from which authoritarian maneuvers almost inevitably originate. The mobilization of identity politics lends itself particularly well to actors without direct access to executive power because it can be 
achieved, to a large extent, through social media and other non-governmental ways of political communication. $^{37}$

While identity politics draws from existing social tensions and resentments, it is its deliberate utilization by political actors that turns it into an innovative authoritarian tool. In Indonesia, rising anti-globalization sentiments and dissatisfaction with socioeconomic inequalities had prepared a fertile ground for identity politics, ${ }^{38}$ but it needed political agents for it to be successfully weaponized. Opinion surveys have demonstrated just how effective this weaponization has been. Before the Islamist mobilization of 2016, for instance, polls highlighted that intolerance among Indonesian Muslims towards non-Muslims had been in decline. It was only after the mobilization that this intolerance increased rapidly: the percentage of Indonesian Muslims rejecting non-Muslims holding the political post of governor rose from $42 \%$ in 2016 to 55\% in 2018 - underlining that the broader Muslim population had endorsed the key campaign message of the protest leaders. ${ }^{39}$

As in the case of electoral narrowing, the deployment of identity politics was an effective authoritarian innovation because it could be packaged in the language of democracy. Far from acknowledging that whipping up anti-minority sentiments eroded democracy and justice, the actors behind identity politics insisted that they were defending both. In the Ahok case, for example, protesters portrayed their actions as a fight for the rule of law - claiming that the state was reluctant to use the blasphemy law because of the governor's relations with the president. Similarly, Prabowo's Islamist allies justified their attack on the ethnic Chinese ${ }^{40}$ as an act of fighting the elite's corruption. Tellingly, surveys showed that most Prabowo voters supported democracy ${ }^{41}$ - demonstrating that identity politics could be used to hollow out democracy without the voters mobilized for that effort even recognizing their antidemocratic instrumentalization. At the end, even Jokowi felt pressured to tap into the power of identity politics in order to neutralize it as an electoral instrument directed against him. In August 2018, he named Ma'ruf Amin, a senior cleric who had signed the fatwa confirming that Ahok had committed blasphemy, as his running mate for the 2019 elections - in which he faced Prabowo again. After another campaign marked by hardening identity politics, Jokowi beat Prabowo for a second time, with a margin only slightly increased from 2014.

It would be misleading to read Prabowo's failures in 2014 and 2019, as well as his joining of the Jokowi government as defence minister in October 2019, as proof for the ineffectiveness of identity politics in Indonesia (and, by implication, the resilience of pluralism and democracy). ${ }^{42}$ First, as indicated above, both candidate pairs applied identity politics in 2019 - entrenching it as an acceptable political tool. Second, Prabowo's split with the Islamists after the 2019 elections, and his entry into cabinet, do not remove the Islamist constituency itself - efforts are already under way in the Islamist community to find a new candidate for 2024, with Jakarta governor Anies Baswedan (who defeated Ahok in 2016 with the help of the Islamists) currently seen as the leading candidate for that role.

\section{Executive illiberalism}

While some of Indonesia's oppositional forces were the main drivers of using identity politics as an innovative authoritarian tool, it remains true that executive incumbents play a leading role in other illiberal or quasi-authoritarian trends. These concern, in 
Indonesia and elsewhere, attempts by government leaders to increase their executive powers at the expense of the legislature, the judiciary and society. Such projects of power concentration often result in the erosion of constitutional democracy, and according to Merkel - its replacement by illiberal or delegative democracy. While Merkel distinguishes illiberal and delegative democracies (in the latter, "governments, usually led by charismatic presidents, circumvent parliament, influence the judiciary, damage the principle of legality, undermine checks and balances, and shift the equilibrium of the balance of power unilaterally" ${ }^{43}$ in favour of the presidential executive), the differences between them are minimal. Indeed, both describe inherently illiberal practices operating in formally democratic polities. As this section shows, the Jokowi government used the authoritarian tactics mentioned by Merkel to stifle the opposition, further illiberalizing an already defective democracy.

Echoing the opposition's authoritarian initiatives, the government too cloaked its executive measures of power concentration as necessary actions in defense of Indonesian democracy. This approach began with the immediate post-election period between 2014 and 2016, but intensified following the Islamist mobilization against Ahok and the president in 2016. In both periods, Jokowi believed that democracy was under threat: first, from the majority of pro-Prabowo parties in the legislature, which controlled $62 \%$ of parliamentary seats; and later, from the extra-parliamentary opposition mobilized by Islamists in alliance with a number of establishment figures. Both contexts justified, in the view of Jokowi and his associates, the use of strong executive instruments against an anti-democratic opposition. ${ }^{44}$ But masked by the rhetoric of democracy defense, the Jokowi government launched a package of authoritarian innovations that marked a noticeable break with democratic traditions created since 1998.

The first of Jokowi's authoritarian innovations came in the form of heavy-handed interventions into the internal affairs of opposition parties in order to replace their leaders with loyalists. Since the democratic regime change, presidents had largely refrained from interfering in the internal matters of parties other than their own. In 2015 and 2016, by contrast, the Jokowi government intervened in conflicts between pro-Prabowo and pro-Jokowi factions in two key parties that were in opposition at that time - Suharto's former electoral machine Golkar and the Islamic United Development Party (Partai Persatuan Pembangunan, PPP). In both cases, the government withdrew recognition from the two parties' incumbent pro-Prabowo leadership boards and transferred it to their pro-Jokowi challengers. ${ }^{45}$ This move allowed Jokowi to turn his minority position in parliament into a majority. Officially, the government denied accusations of intervention. But privately, Jokowi associates pointed to the anti-democratic posture of the party factions that had been replaced: both had supported Prabowo's sectarian campaign in 2014 . $^{46}$ Nevertheless, the president's meddling in the autonomy of political parties undermined an important pillar of the democratic architecture.

While the president tightened his grip on political parties, he also gave himself the authority to ban non-governmental organizations. Under Yudhoyono, a 2013 law had already equipped the executive with the right to initiate bans of social organizations, but had handed the final decision on such actions to the judiciary. As a result of this law, Freedom House had downgraded Indonesia's status from "free" to "partly free" in 2014. However, Jokowi further boosted the power of the executive vis-à-vis civil society by issuing an emergency decree in July 2017 that allowed the government to ban any organization without prior judicial process. ${ }^{47}$ Shortly after its promulgation, the government used the decree to ban the ultra-conservative but non-violent Islamist group 
Hizbut Tahrir Indonesia, which had been one of the organizers of the anti-Ahok protests. This marked the first time since Suharto's fall that a major non-violent organization had been banned. Once again, Jokowi's assistants framed this move as one of democracy defense. Pointing to the corrupt and conservative nature of the Indonesian judiciary, they argued that leaving decisions on bans of Islamist groups to the courts risked that the judges would side with the latter. ${ }^{48}$ In the belief that only it could act impartially, the government absorbed powers from the judiciary and tilted the balance with civil society in its favour.

A particularly innovative authoritarian technique used by the Jokowi government has been the criminalization of opponents on account of a systematic fight against the antidemocratic threat of "fake news". Using existing defamation and electronic information laws (an article in the criminal code on insulting the president had been annulled by the Constitutional Court in 2006), the government pursued government critics online and offline, with a particular focus on those associating Jokowi with communism. In some cases, the police arrested suspects and discontinued the cases after forcing the individuals to apologize. ${ }^{49}$ In other cases, the "perpetrators" were sentenced to prison (such as the preacher Alfian Tanjung, who received a prison term of two years in 2017). In portraying these arrests as part of a legitimate campaign against disinformation spread by anti-democratic forces, the Jokowi government connected with a worldwide discourse on this issue (France passed a law on "fake news" in July 2018). Conveniently, however, the vast majority of the government's targets were Jokowi detractors. In January 2019, Ahmad Dhani, a close Prabowo associate, was sentenced to 18 months in prison for tweets that supposedly defamed all Ahok supporters (and thus, the president).

This anti-hoax campaign against opposition figures coincided with more conventional criminalization efforts against government critics. In one case, this resulted in the exiling of the critic concerned - a phenomenon not seen since the Suharto regime. Rizieq Shihab, the leader of the Defenders of Islam Front (Front Pembela Islam, FPI) and the key figure behind the anti-Ahok demonstrations, had emerged as Jokowi's main extra-parliamentary opponent in late 2016. Precisely at that juncture, the Indonesian police brought a series of cases against him, ranging from defaming the state ideology Pancasila to having shared pornographic pictures with an alleged mistress. In May 2017, Rizieq fled to Saudi Arabia. From there, Rizieq anointed Prabowo as presidential candidate, and campaigned for him by phone. Thus, while the apparent fabrication of criminal cases against a government opponent undermined the principle of rule of law, it did not stop Rizieq's Islamist activism.

The president's instrumentalization of law enforcement agencies also played a role in the deployment of another important authoritarian innovation: the creation of a predominantly pro-government television landscape. ${ }^{50}$ In 2014 , the majority of TV stations (most of them owned by politically connected tycoons) had sided with Prabowo. After Jokowi's rise to power, however, that constellation changed. Key to this shift was Tanoesoedibjo, the chair of Perindro and owner of three TV stations with a combined audience share of $37 \%$ (in 2017). ${ }^{51}$ Tanoesoedibjo had supported Prabowo in 2014, but three years later faced legal investigations over a corporate case. Amidst that investigation, Tanoesoedibjo declared that he would support Jokowi in 2019. His TV channels switched to friendly coverage of the government, ${ }^{52}$ and the investigations into the Perindro chair were frozen. This pro-Jokowi coverage added to that by two other channels owned by Jokowi allies (Metro TV and TV One). Prominent television tycoons Chairul Tanjung and Erick Thohir also supported Jokowi - the latter acted as the president's 
campaign chair. Prabowo's 2019 campaign, on the other hand, enjoyed no support by TV stations.

Finally, Jokowi requested support from government agencies and officials for his reelection. To be sure, such efforts are widespread in democracies, and they have a long tradition in Indonesia too. But mostly such mobilization attempts have been covert in nature. In his 2019 campaign, by contrast, Jokowi openly asked state bodies and leaders for their support. In a speech to military and police officers in August 2018, Jokowi called on both institutions to help promoting (mensosialisasikan) the achievements of the government. ${ }^{53}$ Similarly, the president's campaign pressured governors, district heads and mayors to declare support for Jokowi's re-election - a practice common under Suharto, but unknown in this intensity in the democratic period. By October 2018, the campaign had enlisted support from 30 of Indonesia's 34 governors, and from 359 of 514 district heads and mayors. The exact mechanism through which these serial endorsements were extracted remains unclear: according to insiders, some may have been offered better access to central government funds, while others sought protection from corruption investigations (21 local government heads were arrested for corruption in 2018 alone). ${ }^{54}$ Whatever the reasons, no other postSuharto president had sought and received the electoral support of such a high number of state officials.

Significantly, not all of these authoritarian innovations deployed by Jokowi proved effective. While he increased his margin of victory by about $2 \%$ to achieve an end result of 55.5\%, this was far from what he wanted (his goal had been 60\%). Many provinces that had been Prabowo strongholds in 2014 remained impenetrable for Jokowi, pointing to the ineffectiveness of mobilizing local officials and state officials there. This concurrence of authoritarian innovations and the limitedness of their impact eloquently highlighted the character of Indonesia's contemporary democracy: it emphasized the decline of democratic quality as a result of increasingly illiberal trends, but at the same time demonstrated that despite of all its defects, the post-Suharto polity remains a moderately competitive electoral democracy. Put differently, it would be a mistake to belittle the democracy-damaging effect of the authoritarian innovations because of their limited success - their impact on democratic quality remained serious; but it would be equally wrong to use the existence of authoritarian innovations in Indonesia as evidence for a democratic reversal. It is precisely the operation of authoritarian innovations within the framework of a defective but nominally stable democracy that makes Indonesia such an insightful case study for this phenomenon.

\section{Authoritarian innovations in Indonesia}

It is important to note that none of the quasi-authoritarian and authoritarian innovations described above are in themselves unique in a comparative sense. Indeed, they borrowed from a standard menu of authoritarian techniques used in many countries and contexts, including from Indonesia's own experiences with authoritarianism in the past. But what has made them innovative in the Indonesian case is their application after a period of robust democratization, and their initiators' strategic packaging of those techniques as acts of democracy defense rather than erosion. ${ }^{55}$ In the same vein, the drivers of authoritarian innovations in Indonesia are evenly spread at the collective elite, opposition and executive levels - whereas in most other cases the latter dominates. As such, Indonesia's authoritarian innovations not only 
mark a break in the country's democratic history, they also involve an exceptionally broad mix of actors.

The effectiveness of many of the authoritarian innovations in Indonesia is reflected in the muted response by much of society towards them. A number of social trends have supported this pattern. In the electoral arena, a widespread sense of disdain towards parties and their candidates has translated into sympathy for efforts to reduce their numbers. ${ }^{56}$ At the same time, society's solid opposition towards public funding of parties and candidates has helped elites to sustain patronage-soaked self-funding as the basis of political operations in Indonesia. In the arena of identity politics, elites have been able to exploit deep-seated tribal sentiments and anxieties in the populace. These nativist sentiments have been catalyzed by a growing skepticism towards globalization and the perception that its agents undermine the material and cultural interests of one's own ethnic and religious identity. The prevalence of partisan social media outlets sharpened these identity divisions, ${ }^{57}$ and helped shaping citizens' reactions to illiberal actions by the executive: they were seen as anti-democratic only if they targeted actors on one's own side of the political divide, but viewed as appropriate steps by those opposite.

Despite diverse perceptions in individual cases, the actors' packaging of their authoritarian innovations as democracy-saving secured their overall acceptance by most citizens. Surveys show that the percentage of Indonesians who are satisfied with the way democracy is practiced has remained stable (and high), suggesting that the actions described above are in fact not viewed as anti-democratic by a majority of citizens. ${ }^{58}$ This is despite the fact that international democracy indexes - from the Economist's Democracy Index and Freedom House to V-Dem - have consistently identified trends of democratic decline since the mid-2010s, and a growing literature by (mostly) foreign academics has focused on this backsliding as well. ${ }^{59}$ Importantly, this coincidence of democratic erosion and its non-recognition by most Indonesians highlights the often "insidious" and "camouflaging" character of authoritarian innovations in democratic polities.

Quite intentionally, then, Indonesia's authoritarian innovations have damaged its democratic fabric but have not overturned its status as an electoral democracy. Both as a collective and as competing actors, elites have launched initiatives that strengthen their position vis-à-vis society and other elite rivals while upholding the nominal democracy. With this, the Indonesian example fits into a series of comparable cases in which increasingly illiberal democracies fall behind previous democratic achievements but have not, thus far, crossed over into electoral or full authoritarianism. Hungary, Poland or the Philippines are other examples of illiberal democracies in which specific characteristics of democracy (such as minority protections) are systematically undermined, but the formal foundations of democratic institutions remain standing. ${ }^{60}$ Indonesia, despite a successful democratic transition and solid phases of democratic consolidation, appears now to be stuck in this category of a defective, increasingly illiberal democracy - with descent into full authoritarianism as unlikely as return to its consolidation path.

While Indonesia fits into a broader pattern of democratic decline through authoritarian innovations, its case study delivers a number of insights for the comparative debate that other examples don't. First, unlike in cases such as Orban's Hungary, Duterte's Philippines or Erdogan's Turkey, authoritarian innovations in Indonesia have been much less blunt and executive-heavy. This means that their visibility has 
been lower, and thus have been more difficult to detect. One of the reasons for this is that the appetite for aggressively promoted strongman rule remains somewhat limited in Indonesia, and that non-democratic actors hence have to tread more carefully. In a September 2019 poll, 35\% of Indonesian respondents said they could tolerate some form of non-democratic government. ${ }^{61}$ In Hungary, by contrast, $68 \%$ of respondents in 2017 supported government by "experts, not elected officials". ${ }^{62}$ This points to the high level of adaptability of actors with autocratic designs to the environments they operate in - concealed authoritarian innovations are more likely in societies such as Indonesia's, in which open campaigns against democracy are less popular.

Despite this domestic contextualization of authoritarian innovations, the Indonesian case also hightlights - more so than others - how ostensibly democratic politicians draw inspiration from autocrats and populists around the world. Prabowo, for instance, has openly referred to Singapore's Lee Kuan Yew, Thailand's Thaksin Shinawatra and Donald Trump as models for his campaign, while Jokowi copied elements of Duterte's bloody drug war (causing yet another dent to Indonesia's democratic quality) and repeatedly expressed admiration for the effectiveness of governance in non-democratic states such as the Gulf monarchies and China. Apparently influenced by these experiences, Jokowi surprised observers in October 2019 by announcing that Indonesia's political system did not acknowledge the concept of opposition. Indonesia's authoritarian innovations, therefore, have their origins in the country's specific political set of actors and power constellations, but are clearly embedded in a broader philosophy of illiberalism that undermines democratic polities around the world.

\section{Notes}

1. Larry Diamond has been the leading proponent of the idea of a global democratic recession (see Diamond, "Facing Up to the Democratic Recession"). For an opposing view, see Levitsky and Way, "The Myth of Democratic Recession."

2. Diamond, "Facing Up to the Democratic Recession," 144 (all quotes in this paragraph).

3. Smith and Ziegler, "Liberal and Illiberal Democracy in Latin America."

4. Fossati and Curato, "Authoritarian Innovations."

5. Acharya, Indonesia Matters.

6. Tomsa, "Indonesian Politics in 2010."

7. Power, "Jokowi's Authoritarian Turn."

8. Mietzner, "Fighting Illiberalism with Illiberalism."

9. Merkel, "Embedded and Defective Democracies."

10. Simonyi, "Putin, Erdogan and Orbán."

11. Merkel, "Embedded and Defective Democracies," 38.

12. Reilly, Democracy and Diversity.

13. Mietzner, Money, Power and Ideology, 66.

14. Reilly, Political Engineering and Party Politics.

15. Hadiz, "The Indonesian Labour Movement."

16. Mudhoffir, "Millenials Won't Rescue Indonesia."

17. Power, "Jokowi's Authoritarian Turn," 321.

18. Ibrahim, "Naik-Turun Jumlah Calon."

19. Aspinall et al., Vote Buying in Indonesia; Ufen, "Electoral Campaigning in Indonesia."

20. Van Biezen, "State Intervention in Party Politics."

21. Mietzner, "Dysfunction by Design."

22. Muhtadi, "Buying Votes in Indonesia."

23. Data from Yayasan Api, Panduan Parlamen Indonesia; Wajah DPR dan DPD; as well as information sent to the author by Indonesian Corruption Watch (ICW).

24. Interview with a Golkar legislator, Jakarta, 15 May 2014. 
25. Katz and Mair, "The Cartel Party Thesis."

26. Slater, "Party Cartelization, Indonesian-Style."

27. Davidson and Henley, The Revival of Tradition.

28. Fukuyama, "Against Identity Politics."

29. Merkel, "Embedded and Defective Democracies," 40.

30. Cohen, "'Us' vs 'Them'."

31. Aspinall, Mietzner and Tomsa, "The Moderating President."

32. In 2014, he used to word "antek asing," or foreign accomplice, to describe rich elites associated with foreign interests. While not made explicit, it was widely understood in Indonesia to at least prominently include ethnic Chinese entrepreneurs.

33. Dunia Muallaf, "Jokowi Pembawa Masalah."

34. Aspinall and Mietzner, "Vote for Me."

35. Scherpen, "Is Hardline Islam Really Rising in Indonesia?"

36. Mietzner and Muhtadi, "Explaining the 2016 Islamist Mobilisation."

37. Bennett, "The Personalization of Politics."

38. Kawamura, "Politics of Inequality."

39. Mietzner and Muhtadi, "The Mobilisation of Intolerance."

40. Bangka Pos, "Amien Rais."

41. Data provided to the author by Lembaga Survei Indonesia (LSI).

42. Bayuni, "Less Polarised Indonesia."

43. Merkel, "Embedded and Defective Democracies," 50.

44. Interview with two close Jokowi advisers, Jakarta 10 November 2016.

45. For the details of how this was done, see Mietzner, "Coercing Loyalty."

46. Interview with a Jokowi minister, Jakarta, 15 May 2016.

47. Aspinall, "Twenty Years of Indonesian Democracy."

48. Interview with a senior official in the Office of the Chief of Staff of the President, Jakarta, 13 September 2017.

49. Inews, "Dipolisikan, Begini Nasib Pelaku Penghina Jokowi."

50. Tapsell, Media Power in Indonesia.

51. Nielsen Indonesia, "Audience Share."

52. Apinino, "Ramai-Ramai Pemilik Media."

53. Power, "Jokowi's Authoritarian Turn," 333.

54. Interview with a Golkar legislator, Jakarta, 21 September 2018.

55. Aspinall, "Twenty Years of Indonesian Democracy."

56. Johnson Tan, "Reining In the Reign of the Parties."

57. Lim, "Freedom to Hate."

58. Satisfaction with the way democracy is practiced in Indonesia rose from $69 \%$ to $73 \%$ between 2017 and 2018. Data provided by Lembaga Survei Indonesia.

59. Hadiz, "Indonesia's Year of Democratic Setbacks"; Warburton and Aspinall, "Indonesian Democracy."

60. Greskovits, "The Hollowing and Backsliding of Democracy."

61. LSI, Survey on Religious Tolerance.

62. Pivarnyik, "Hungarians want an Expert Government."

\section{Disclosure statement}

No potential conflict of interest was reported by the author.

\section{Notes on contributor}

Marcus Mietzner is an Associate Professor at the Coral Bell School of Asia Pacific Affairs at the Australian National University in Canberra. During the time of writing, he was Visiting Research Scholar at the Center for Southeast Asian Studies at Kyoto University. He is the author of Reinventing Asian Populism: Jokowi's Rise, Democracy, and Political Contestation in Indonesia (East West Center, Hawaii). 


\section{Bibliography}

Acharya, Amitav. Indonesia Matters: Asia's Emerging Democratic Power. Singapore: World Scientific Publishing, 2014.

Apinino, Rio. "Ramai-ramai Pemilik Media Merapat ke Jokowi Buruk untuk Demokrasi." Tirto, September 8, 2018.

Aspinall, Edward. “Twenty Years of Indonesian Democracy-How Many More?” New Mandala, May 24, 2018.

Aspinall, Edward, and Marcus Mietzner. "Prabowo Subianto: Vote for Me, But Just the Once." New Mandala, June 30, 2014.

Aspinall, Edward, Marcus Mietzner, and Dirk Tomsa. “The Moderating President: Yudhoyono's Decade in Power." In The Yudhoyono Presidency: Indonesia's Decade of Stability and Stagnation, edited by Edward Aspinall, Marcus Mietzner, and Dirk Tomsa, 1-21. Singapore: ISEAS, 2015.

Aspinall, Edward, Noor Rohman, Ahmad Zainul Hamdi, Rubaidi and Zusiana Elly Triantini. "Vote Buying in Indonesia: Candidate Strategies, Market Logic and Effectiveness." Journal of East Asian Studies 17, no. 1 (2017): 1-27.

Bangka Pos. "Amien Rais: Pak Jokowi, Negara Jangan Dijual ke Aseng atau Asing." Bangka Pos, December 2, 2017.

Bennett, W. Lance. "The Personalization of Politics: Political Identity, Social Media, and Changing Patterns of Participation." The Annals of the American Academy of Political and Social Science 644, no. 1 (2012): 20-39.

Bayuni, Endy M. "Less Polarized Indonesia Offers Some Respite for Democracy." The Jakarta Post, November 4, 2019.

Cohen, Margot. “'Us' vs 'Them'.” Far Eastern Economic Review, February 12, 1998.

Davidson, Jamie S., and David Henley, eds. The Revival of Tradition in Indonesian Politics. The Deployment of Adat from Colonialism to Indigenism. London \& New York: Routledge, 2007.

Diamond, Larry. "Facing Up to the Democratic Recession." Journal of Democracy 26, no. 1 (2015): 141155.

Dunia Muallaf. "Habib Rizieq Syihab: 'Jokowi Pembawa Masalah dan Pengundang Musibah Bagi Umat Islam!'” Dunia Muallaf, November 2014.

Fossati, Diego, and Nicole Curato. "Authoritarian Innovations: Crafting Support for a Less Democratic Southeast Asia." Unpublished Paper, 2018.

Greskovits, Béla. "The Hollowing and Backsliding of Democracy in East Central Europe." Global Policy 6, no. 1 (2015): 28-37.

Hadiz, Vedi R. “The Indonesian Labour Movement: Resurgent or Constrained?" Southeast Asian Affairs (2002): 130-142.

Hadiz, Vedi R. "Indonesia's Year of Democratic Setbacks: Towards a New Phase of Deepening Illiberalism?" Bulletin of Indonesian Economic Studies Volume 53, no. 3 (2017): 261-278.

Ibrahim, Gibran Maulana. "Naik-Turun Jumlah Calon di Pilkada Dinilai karena Biaya Politik Mahal." DetikNews, January 13, 2018.

Inews. “Dipolisikan, Begini Nasib Pelaku Penghina Presiden Jokowi.” Inews, May 25, 2018.

Johnson Tan, Paige. "Reining in the Reign of the Parties: Political Parties in Contemporary Indonesia." Asian Journal of Political Science 20, no. 2 (2012): 154-179.

Katz, Richard S., and Peter Mair. “The Cartel Party Thesis: A Restatement.” Perspectives on Politics 7 , no. 4 (2009): 753-766.

Kawamura, Koichi. "Politics of Inequality in Indonesia: Does Democracy Matter?" In Emerging States at Crossroads, edited by Keiichi Tsunekawa and Yasuyuki Todo, 231-253. Heidelberg: Springer, 2018.

Levitsky, Steven, and Lucan Way. "The Myth of Democratic Recession." Journal of Democracy 26, no. 1 (2015): 45-58.

Lim, Merlyna. "Freedom to Hate: Social Media, Algorithmic Enclaves, and the Rise of Tribal Nationalism in Indonesia." Critical Asian Studies 49, no. 3 (2017): 411-427.

LSI (Lembaga Survei Indonesia). Survey on Religious Tolerance. Jakarta: LSI, September 2019.

Merkel, Wolfgang. "Embedded and Defective Democracies." Democratization 11, no. 5 (2004): 33-58.

Mietzner, Marcus. Money, Power, and Ideology: Political Parties in Post-Authoritarian Indonesia. Honolulu: Hawaii University Press, 2013. 
Mietzner, Marcus. "Dysfunction by Design: Political Finance and Corruption in Indonesia'." Critical Asian Studies 47, no. 4 (2015): 587-610.

Mietzner, Marcus. "Coercing Loyalty: Coalitional Presidentialism and Party Politics in Jokowi's Indonesia." Contemporary Southeast Asia 38, no. 2 (2016): 209-232.

Mietzner, Marcus. "Fighting Illiberalism with Illiberalism: Islamist Populism and Democratic Deconsolidation in Indonesia." Pacific Affairs 91, no. 2 (2018): 261-282.

Mietzner, Marcus, and Burhanuddin Muhtadi. "Explaining the 2016 Islamist Mobilisation in Indonesia: Religious Intolerance, Militant Groups and the Politics of Accommodation." Asian Studies Review 42, no. 3 (2018): 479-497.

Mietzner, Marcus, and Burhanuddin Muhtadi. "The Mobilization of Intolerance and its Trajectories: Indonesian Muslims' Views of Religious Minorities and Ethnic Chinese." In Contentious Belonging: The Place of Minorities in Indonesia, edited by Greg Fealy and Ronit Ricci, 155-174. Singapore: ISEAS Publishing, 2019.

Mudhoffir, Abdil Mughis. "Millennials Won't Rescue Indonesia." New Mandala, May 2, 2018.

Nielsen Indonesia. "Audience Share Stasiun Televisi Nasional Saat Prime Time pada Maret 2017."

Pivarnyik, Balázs. "Hungarians Want an Expert Government, Reject Representative Democracy." The Budapest Beacon, October 18, 2017.

Power, Thomas P. "Jokowi's Authoritarian Turn and Indonesia's Democratic Decline." Bulletin of Indonesian Economic Studies 54, no. 3 (2018): 307-338.

Reilly, Benjamin. "Political Engineering and Party Politics in Conflict-Prone Societies." Democratization 13, no. 5 (2006): 811-827.

Reilly, Benjamin. Democracy and Diversity: Political Engineering in the Asia-Pacific. Oxford: Oxford University Press, 2007.

Simonyi, Andras. "Putin, Erdogan and Orbán: Band of Brothers?” New Perspectives Quarterly 31, no. 4 (2014): 33-35.

Slater, Dan. "Party Cartelization, Indonesian-Style: Presidential Power-Sharing and the Contingency of Democratic Opposition." Journal of East Asian Studies 18, no. 1 (2018): 23-46.

Smith, Peter H., and Melissa R. Ziegler. "Liberal and Illiberal Democracy in Latin America." Latin American Politics and Society 50, no. 1 (2008): 31-57.

Tomsa, Dirk. "Indonesian Politics in 2010: The Perils of Stagnation." Bulletin of Indonesian Economic Studies 46, no. 3 (2010): 309-328.

Ufen, Andreas. "Electoral Campaigning in Indonesia: The Professionalization and Commercialization After 1998." Journal of Current Southeast Asian Affairs 29, no. 4 (2010): 11-37.

van Biezen, Ingrid. "State Intervention in Party Politics: The Public Funding and Regulation of Political Parties." European Review 16, no. 3 (2008): 337-353.

Wajah DPR dan DPD, 2009-2014: Latar Belakang Pendidikan dan Karier [The Faces of the DPR and DPD: Educational and Career Backgrounds]. Jakarta: Penerbit Buku Kompas, 2010.

Warburton, Eve, and Edward Aspinall. "Indonesian Democracy: From Stagnation to Regression?" The Strategist, August 17, 2017.

Yayasan Api. Panduan Parlemen Indonesia [Guidebook for the Indonesian Parliament]. Jakarta: Yayasan Api, 2001. 